\title{
Lean Implementation in Jordanian Pharmaceutical Industry: The Case of Hikma Company
}

\author{
Emad Ahmed \\ Assistant Professor, Arab Open University-Jordan \\ Walid Saleh \\ Associate Professor, Arab Open University \\ Yasmeen Khashman \\ Independent researcher
}

\begin{abstract}
The purpose of this paper was to investigate the effect of lean practices on productivity at process industries; the case of Hikma Pharmaceutical Company. A quantitative approach based on survey questionnaire was used to evaluate the impact of lean tools on productivity. The paper showed that visual management, $5 \mathrm{~S}$, and work standards had a significant impact on productivity, whereas, waste reduction did not have a significant effect.
\end{abstract}

Keywords: Lean practices, productivity, pharmaceutical industry.

DOI: $10.7176 / \mathrm{EJBM} / 13-10-08$

Publication date:May $31^{\text {st }} 2021$

\section{Introduction}

Sohal (1996) argued that lean production solves problems through continuous improvements and thus eliminates unnecessary processes. Lean management implements some set of lean practices to identify and eliminate process that do not create value for the end users. Womack and Jones (1996) confirmed that, irrespective to the type of business, lean management is concerned with adding value to customers'.

However, Avinash (2015) argued that it is essential to examine whether adoption of lean in process industries (e.g. Pharmaceutical) is significantly beneficial for the business or not. For instance, Pharmaceutical Companies have continuous process; non discrete materials that cannot be conducted without containerization ${ }^{1}$. Thus, Pharmaceutical Companies cannot apply some lean techniques such as just-in-time (JIT) since these companies have long term setups with large batch sizes. Therefore, the level of inventory will be high in whole supply chain with very low material efficiencies (Shah, 2005). Furthermore, Pharmaceutical Companies have seasonal availability of raw materials and huge processing equipments (Melton, 2005), and thus, raw materials, finished goods, and auxiliary materials occupy huge spaces. Cox and Chicksand (2005) suggested that lean can assist in achieving better utilization of space and equipments.

In addition, Pharmaceutical Companies have high degree of automation and thus, processing cannot be stopped in between because it yields to a huge loss of productivity. Sharma et al. (2005) suggested that lean practices such as $5 \mathrm{~S}$ and total productive maintenance are the most effective way to keep them working all the time without breakdowns. Also, setup time is an important issue in Pharmaceutical processes since it consists of cleaning of processing equipments. Therefore, Billesbach (1994) confirmed that setup time reduction and quick changeover techniques can be very effective to reduce cost.

An additional advantage of lean in Pharmaceutical industry is that it results in lead time reduction (e.g. Cook and Rogowski, 1996). Finally, Shah and Ward (2003) reported that lean tools are widespread in all industries regardless of its type. Moreover, Sohal and Egglestone (1994) found that substantial benefits can be achieved through implementation of lean despite of the type of industry.

The main aim of this paper was to investigate the effect of lean practices on the operational performance at Hikma Company and to determine the best lean tools that are suitable to the company.

The paper concluded that visual management, standard work, and $5 \mathrm{~S}$ tools have a significant effect on increasing productivity. However, the paper reported that waste reduction tools do not have a significant impact on productivity.

\section{Research Methodology and Data Collection}

The paper aimed at analyzing lean practices that could influence operational performance (productivity) of Hikma Company. The time span for data collection was from March, 2015 to May, 2015. The paper used a quantitative approach based on a survey questionnaire broken down into five sections. This questionnaire was reviewed by

\footnotetext{
${ }^{1}$ Note that lean concept was first applied by Toyota to reduce waste during production and that such types of industries applied discrete materials.
} 
expert in the field. The selection of lean tools was based on literature review, experts, and staff members at Hikma. These tools are visual management, 5S, standard work, and waste reduction. The questionnaire consisted of two parts. The first part contained questions about gender, country, job title, and age. The second part covered the questions related to each lean tool or technique ${ }^{2}$. Table-1 summarizes sample descriptive statistics.

Table 1: Sample Characteristics

\begin{tabular}{|c|c|c|c|}
\hline \multirow{2}{*}{ Variable } & Frequency & Valid Percentage (\%) \\
\hline \multirow{3}{*}{ Gender } & Male & 79 & 74.5 \\
\cline { 2 - 4 } & Female & 27 & 25.5 \\
\hline \multirow{3}{*}{ Age } & 30 years or less & 63 & 60.6 \\
\cline { 2 - 4 } & $31-40$ & 33 & 31.7 \\
\cline { 2 - 4 } & 41 years and above & 8 & 7.7 \\
\hline \multirow{3}{*}{\begin{tabular}{c} 
Job title \\
\cline { 2 - 4 } Country
\end{tabular}} & Manager & 16 & 16.5 \\
\cline { 2 - 4 } & Supervisor/ Officer & 55 & 56.7 \\
\cline { 2 - 4 } & Operator & 26 & 26.8 \\
\cline { 2 - 4 } & Jordan & 137 & 89.5 \\
\cline { 2 - 4 } & Tunisia & 1 & 0.7 \\
\hline
\end{tabular}

Note that out of 300 questionnaires sent to Hikma' employees (mangers, supervisors, and operators), 153 responded were valid and that not all of them provide information on the first part of the questionnaire.

\section{Results}

\subsection{Descriptive Statistics}

Table- 2 presents the average and standard deviation for each lean tool. On average, it appears that respondents had high scores (above 3.8) for all lean practices, except for waste reduction; the average is 3.42. This result suggests that $5 \mathrm{~S}$, standard work, and visual management have an effect on productivity greater than waste reduction.

Table 2: Lean Practices-Descriptive Statistics

\begin{tabular}{|l|c|c|c|}
\hline & Mean & Std. Deviation & No. \\
\hline FiveS & 3.83 & 1.207 & 153 \\
\hline Wastred & 3.42 & .935 & 153 \\
\hline Standwok & 4.10 & .638 & 153 \\
\hline Vismangt & 3.88 & .698 & 153 \\
\hline Productivity & 3.94 & .632 & 153 \\
\hline
\end{tabular}

\subsection{Research validity and reliability}

To validate the appropriateness of the proposed framework, the researchers applied a confirmatory factor analysis (CFA) to confirm whether the items actually belong to the factors for which they are theoretically designed. Next, the researchers tested the reliability of the analysis (how the items in the test are interrelated among themselves). The Cronbach's Alpha was around 0.70, which suggests that the model is reliable.

\subsection{The effect of lean practices on productivity}

To test the effect of lean practices (5S, Waste Reduction, Standard Work and Visual Management) on the productivity, the researchers conducted a multiple regression analysis (stepwise). The results (Table-3) showed that visual management, standard work, and $5 \mathrm{~S}$ are significant at 5 percent level. The P-value is less than 0.05 . The above result confirms that the model is valid and was able to explain $30.4 \%$ of the productivity at Hikma Company.

\begin{tabular}{|c|c|c|c|c|c|}
\hline Model & R & R Square & $\begin{array}{c}\text { Adjusted R } \\
\text { Square }\end{array}$ & $\begin{array}{c}\text { Std. Error of } \\
\text { the Estimate }\end{array}$ & $\begin{array}{c}\text { Durbin- } \\
\text { Watson }\end{array}$ \\
\hline VM & $.499 \mathrm{a}$ & .249 & .244 & .550 & \multirow{2}{*}{1.497} \\
\hline VM and SW & $.542 \mathrm{~b}$ & .294 & .284 & .535 & .527 \\
\hline VM, SW, and 5S & $.564 \mathrm{c}$ & .318 & $\mathbf{. 3 0 4}$ & & \\
\hline
\end{tabular}

Where, VM is visual management, and SW is standard work.

\footnotetext{
${ }^{2}$ Note that a five point Likert scale was used to measure the effect of lean practices on productivity, whereas, $1=$ "strongly disagree" and $5=$ "strongly agree".
} 


\section{Conclusion}

Historically, the Pharmaceutical Industry has been very profitable. However, more competitors have appeared in recent years which lead these pharmaceutical companies to focus on cost reduction to sustain their profits. Lean Management has been adopted in international pharmaceutical companies to achieve cost reduction. Lean culture, which was first developed by Toyota, is recommended as a mean to achieve a competitive advantage in the manufacturing operations. Lean Management is one of the known strategies currently used to eliminate various hidden wastes that don't add value to products/customers'.

Proceeding from this point, the aim of this research was to investigate the effect of lean management on the Operational Performance at Hikma Pharmaceutical Company. In conclusion the paper reported that lean practices such as visual management, $5 \mathrm{~S}$, and standard work have a significant impact on productivity.

\section{References}

Avinash Rathore , (2015),"Lean implementation in Indian process industries: some empirical evidence", Journal of Manufacturing Technology Management, Vol. 26 Issue 1.

Billesbach, J.T. (1994), “Applying lean production principles to a process facility”, Production and Inventory Management Journal, Vol. 35, pp. 40-44.

Cox, A. and Chicksand, D. (2005), "The limits of lean management thinking: multiple retailers and food and farming supply chains", European Management Journal, Vol. 23 No. 6, pp.648-662.

Cook, R.C. and Rogowski, R.A. (1996), "Applying JIT principles to continuous process manufacturing supply chains", Production \& Inventory Management Journal, Vol. 37 No.1, pp. 12-16.

Melton, T. (2005), "The benefits of lean manufacturing: what lean thinking has to offer the process industries", Chemical Engineering Research and Design, Vol. 83 No. A6, pp. 662-673

Shah, N. (2005), "Process industry supply chains: advances and challenges", Computers and Chemical Engineering, Vol. 29 No. 6, pp. 1225-1235.

Shah, R. and Ward, P.T. (2003), "Lean manufacturing: context, practices bundles, and performance", Journal of Operations Management, Vol. 21No. 2, pp. 129-149.

Sharma, R. K., Kumar, D. and Kumar, P. (2005), "FLM to select suitable maintenance strategy in process industries using MISO model”, Journal of Quality in Maintenance Engineering, Vol. 11 No. 4, pp. 359-374.

Sohal, A.S. (1996), "Developing a lean production organization: an Australian case study", International Journal of Operations and Production Management, Vol. 16 No.2, pp. 91-102.

Sohal, A.S. and Egglestone, A. (1994), "Lean production: experience among Australian organizations", International Journal of Operations \& Production Management, Vol. 14 No. 11, pp. 35-51.

Womack, J.P. and Jones, D.T. (1996), Lean Thinking: Banish Waste and Create Wealth in Your Corporation, Simon and Schuster, New York. 